\title{
Heat Consumption Assessment of the Domestic Hot Water Systems in the Apartment Buildings
}

\author{
Dzintars Grasmanis ${ }^{1}$, Normunds Talcis ${ }^{2}$, Aldis Grekis ${ }^{3}$, \\ ${ }^{1,2,3}$ Riga Technical University
}

\begin{abstract}
This study presents the analysis of energy consumption for domestic hot water in apartment buildings in Riga, Latvia. The aggregate data contains information about 39 apartment buildings, including heat energy consumption and domestic hot water (DHW) consumption. The analysis is focused on the heat energy consumption and seasonal characteristics in the DHW system.

The analysis characterizes the DHW consumption, energy consumption for DHW and energy losses in the DHW systems in apartment buildings.
\end{abstract}

Keywords - Apartment buildings, domestic hot water (DHW), heat consumption, heat gains and heat losses.

\section{INTRODUCTION}

The energy consumption of DHW needs of households and some other building sectors constitutes a significant part of the building's energy balance.

The building energy efficiency improvement measures reduce the heating energy required proportion and logically increase the share of energy consumption for DHW needs. It is likely that the production and distribution of DHW in buildings will constitute a dominant share of both the present, and in particular, the future energy design requirements of buildings. [1]

Previously studies carried out in various European countries [2], [3], [4], China [5], [6], Japan [7], [8], [9], USA [10], [11], Canada [12] points the many differences in DHW consumption as well as the tendency to change over time due to a global increase of energy prices, changes in technologies, introducing of individual metering, as well as wide variety of other factors that may appear on local or regional level.

Measurements in Denmark documented not only a relatively high energy consumption for DHW in apartment buildings, but also recorded surprisingly large heat losses from the DHW circulation lines [13], [14]. Recent investigation of 24 buildings in Danmark shows that most of the energy demand for DHW is lost in the circulation system. The efficiency was $0.30-0.77$ (heat loss 23-70\%) in apartment buildings and efficiency $0.11-$ 0.46 (heat loss 54-89\%) in office buildings. [1]

The Energy Performance of Buildings Directive (EPBD) [15] in the version of 2010, the so-called recast EPBD, demands in annex I 'Common general framework for the calculation of energy performance of buildings (referred to in Article 3)' that '(1) the energy performance of a building shall be determined on the basis of the calculated or actual annual energy that is consumed in order to meet the different needs associated with its typical use and shall reflect the heating energy needs and cooling energy needs (energy needed to avoid overheating) to maintain the envisaged temperature conditions of the building, and domestic hot water needs'. This is one of essential requirements already established by the EPBD in the version of 2002 [16].

In Latvia, EPBD requirements have been transposed by the Law on the Energy Performance of Buildings (13 ${ }^{\text {th }}$ March 2008, recast $6^{\text {th }}$ December 2012). The calculation procedures are prescribed by the Cabinet Regulation on the Calculation of Energy Performance of Buildings (No. 348 as of $25^{\text {th }}$ June 2013 replace previous No. 39 as of $13^{\text {th }}$ January 2009).

The structure that should be used for the calculation of energy use in space heating systems and domestic hot water systems in buildings is specified in standard EN 15316-1 [17].

The objective of the calculation is to contribute to the evaluation of the annual energy use of the space heating and domestic hot water systems. If there is seasonal heating in the building, the year should at least be divided into two calculation periods, i.e., the heating season and the rest of the year. Different levels of detail may be used for the different subsystems of the heating system. However, it is essential that the results correspond to the defined output values of the subsystem: - energy input; - energy output; - system thermal losses; - recoverable system thermal losses; - auxiliary energy; in order to ensure proper links to calculations for the following sub-systems and development of a common structure. [18]

According to the CEN standards, the energy consumption for domestic hot water (DHW) production is calculated using a three-step approach: 1) building DHW needs, 2) distribution and 3) generation. The correct estimation of the domestic hot water needs is essential. This results in volume and time of hot water needs throughout the year (the gross hot water demand) and tapping patterns. Tapping patterns are important for the calculation of distribution and generation losses. Also the estimation of the contribution of each heat generator (e.g., thermal solar) depends on the tapping patterns. The second step comprises the calculation of the distribution systems. This part of a domestic hot water system is all between the generation system and the point of tapping. Important aspects to be considered in this respect are heat losses and pump energy. The distribution losses can be higher than the domestic hot water needs. The gross hot water needs are delivered by heat generators. There are several types of generators available, and many of them are also used to provide space heating. Space heating and domestic hot water have some distinctively different properties, so there are separate standards on DHW and space heat generation. DHW is different from space heating 
in that the heat demand has an interval character and a different temperature level [19].

The correct characterization of hot water needs is important because the losses of boilers and the distribution system are very sensitive to the couple of frequency and energy content of heat up and cool down at any tapping. Therefore, the needs are defined by the energy amount and also by the tapping patterns. The energy amount of hot water needs could represent about $25 \%$ of the final heating needs (or 20 to $25 \mathrm{kWh} / \mathrm{m}^{2}$ per year) in existing residential buildings. The percentage of hot water needs increases in well-insulated houses [20].

The standard EN 15316-3-1 [21] gives four methods for calculation of the energy needs of the delivered domestic hot water:

-energy need related to tapping programs,

-energy need related to volume needs,

-energy need linear with floor area,

-energy need from tabulated values for different building types or functions.

For all methods a national annex is required. The annexes to the standard provide default values. Countries need to decide which method they prefer and which specific energy need, depending on a building type, is suitable.

The EN 15316-3-2 [22] gives methods for calculation of heat losses, the recoverable heat losses and the auxiliary energy of the domestic hot water distribution system.

Domestic hot water distribution systems may consist of a circulation system and/or distribution pipes. Distribution pipe losses are dominated by the heating up and cooling down of the pipes at any tapping, so these losses are sensitive to the tapping pattern [23].

The standard gives five calculation methods for distribution pipe losses:

- heat losses related to floor area,

- heat losses related to pipe lengths - simple method,

- heat losses related to pipe lengths - tabulated data method,

- heat losses related to tapping pattern,

- heat losses based on detailed calculation method.

Circulation systems are in general operated at constant temperature. Therefore circulation system losses do not depend on tapping patterns. Loss reduction may be achieved by applying pipe insulation and night set-back.

The standard gives the following methods to calculate circulation system losses:

- heat losses related to circulation pipe length,

- heat losses based on detailed calculation method,

- heat losses while circulation is off.

The total heat losses are the sum of distribution pipe losses (no circulation loop) and circulation system losses (collective part with circulation loop).Also methods are given to determine auxiliary energy consumption for:

- pumps for circulation systems,

- ribbon or trace heating.
For all methods a national annex is required. The annexes to the standard provide default values.

Dwelling houses are one of the largest district heat users in Latvia. In 2010, Latvian households consumed $70 \%$ of all district heat energy produced [24].

Estimates based on the data aggregated by district heating supplier JSC "Rīgas Siltums" on heat consumption of more than 5,000 residential buildings in Riga city shows that the amount of energy consumed in hot water systems represents an average of $50.9 \mathrm{kWh}$ per square meter of heated apartments annually (fig. 1) or $27 \%$ of the total heat energy consumption in those buildings.

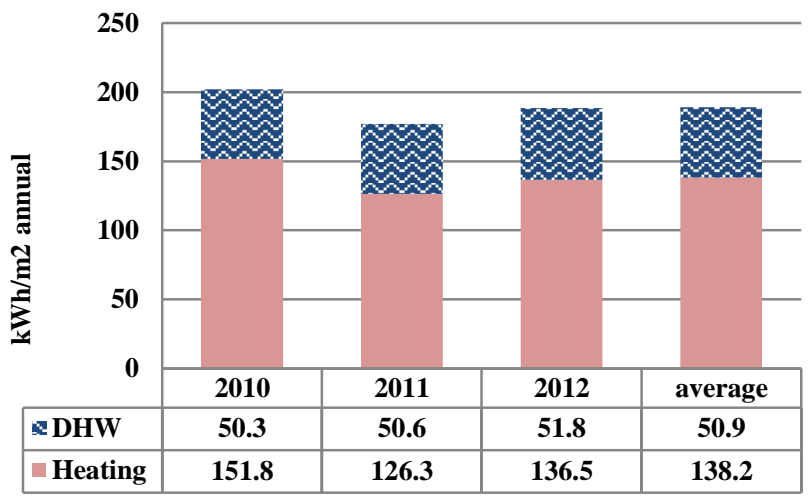

Fig. 1. Yearly consumption of heat energy for heating and DHW needs in apartment buildings connected to district heating in Riga.

Usually apartment buildings have a single heat meter for both heating and DHW in Latvia. Therefore, if the calculation of energy performance of buildings is carried out, the energy use for heating, DHW consumption, circulation loop and others should be assessed separately.

Analysis of the data gives the base to develop methodology for assessment of energy performance of DHW systems adapted for national (Latvia) level.

\section{METHODS}

The authors have analysed the heat energy consumption and water consumption in apartment buildings in Plavnieki and Purvciems area in Riga in the year 2011.

The aggregate data contained information on 39 buildings with 3167 households and total heated area of $158189 \mathrm{~m}^{2}$ in Riga. The total population in these buildings is 7139 inhabitants. The Buildings were constructed by standardized design types from 1966 to 1988; the average heated area of buildings is $3164 \mathrm{~m}^{2}$. Average area per person is $22.3 \mathrm{~m}^{2}$. Buildings have 5 to 12 floors and 1 to 6 sections. Usually each section of the building has separate entrance and similar design with other sections. The characteristics of buildings are given in table 1 . 
TABLE 1

THE CHARACTERISTICS OF THE TYPES OF APARTMENT BUILDINGS

\begin{tabular}{|c|c|c|c|c|c|c|c|c|c|c|c|c|}
\hline $\begin{array}{c}\text { Type of } \\
\text { standar } \\
d \\
\text { design }\end{array}$ & $\begin{array}{l}\text { Number } \\
\text { of } \\
\text { building } \\
\mathrm{s}\end{array}$ & $\begin{array}{c}\text { Year of } \\
\text { constructio } \\
n\end{array}$ & $\begin{array}{c}\text { Numbe } \\
\text { r of } \\
\text { floors }\end{array}$ & $\begin{array}{c}\text { Averag } \\
\mathrm{e} \\
\text { number } \\
\text { of flats }\end{array}$ & $\begin{array}{c}\text { Average } \\
\text { area of } \\
\text { building } \\
\mathrm{s} \\
\mathrm{m}^{2}\end{array}$ & $\begin{array}{c}\text { Averag } \\
\text { e area } \\
\text { of flats, } \\
\mathrm{m}^{2}\end{array}$ & $\begin{array}{l}\text { Average } \\
\text { number of } \\
\text { inhabitant } \\
\text { s }\end{array}$ & $\begin{array}{c}\text { Average } \\
\text { area per } \\
\text { inhabitant } \\
\mathrm{m}^{2}\end{array}$ & $\begin{array}{c}\text { Numbe } \\
\text { r of } \\
\text { section } \\
\text { s }\end{array}$ & $\begin{array}{l}\text { Length } \\
\text { of } \\
\text { section } \\
\text {, m }\end{array}$ & $\begin{array}{c}\text { Width } \\
\text { of } \\
\text { section } \\
\text {, m }\end{array}$ & $\begin{array}{l}\text { Number } \\
\text { of } \\
\text { circulatio } \\
\text { n loops in } \\
\text { section }\end{array}$ \\
\hline 316 & 2 & 1966 & 5 & 70 & 2764 & 39.5 & 138 & 20.5 & 4 & 15.7 & 11.0 & 3 \\
\hline $464 \mathrm{~A}$ & 7 & 1969-1977 & 5 & 54 & 2535 & 47.8 & 127 & 20.0 & 3 or 4 & 13.5 & 11.5 & 3 \\
\hline $104 / \mathrm{m}$ & 2 & 1987 & 5 & 74 & 2655 & 35.5 & 130 & 20.6 & 4 & 13 & 15 & 4 \\
\hline 602 & 15 & 1971-1988 & 9 & 113 & 3363 & 53.2 & 267 & 22.0 & 1 to 6 & 25.6 & 11.2 & 6 \\
\hline $467 \mathrm{~A}$ & 7 & $1977-1987$ & 9 & 54 & 2838 & 52.3 & 124 & 22.7 & 1 to 3 & 25.6 & 11.1 & 6 \\
\hline 104 & 5 & $1979-1981$ & 12 & 71 & 3910 & 54.8 & 141 & 27.8 & 1 & 32 & 15 & 6 \\
\hline
\end{tabular}

Investigated buildings are connected to the district heating network of JSC "Rìgas Siltums". All buildings have the automatic heating 'unit equipped with the heat counters, as well as hot and cold water meters. The measuring equipment belongs to " $\mathrm{B}$ " class meter with error limit \pm 3 percent. There is no separate heat metering for heating and DHW. The draw of DHW system is shown on figure 2 .

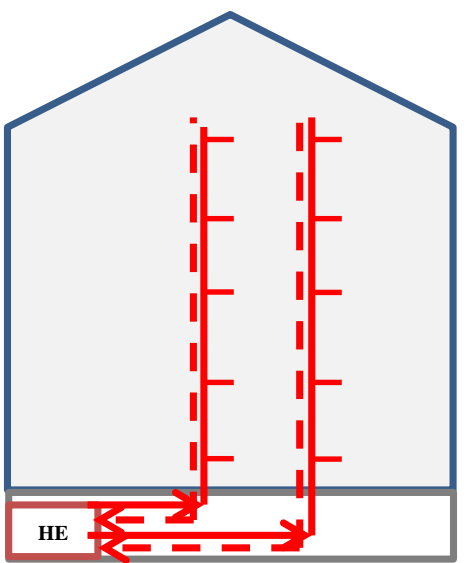

Fig. 2. The DHW circulation system for apartment buildings. (HE - heat exchanger)

\section{RESULTS}

\section{General water consumption characteristics}

For part of buildings have both data for DHW and DCW. The average total water consumption in the 22 investigated buildings in Riga is 3.64 litres per $\mathrm{m}^{2}$ per day annually, of which 1.52 DHW and 2.12 cold water. The consumption of domestic cold water and domestic hot water per $\mathrm{m}^{2}$ per day is shown in Fig. 3 .

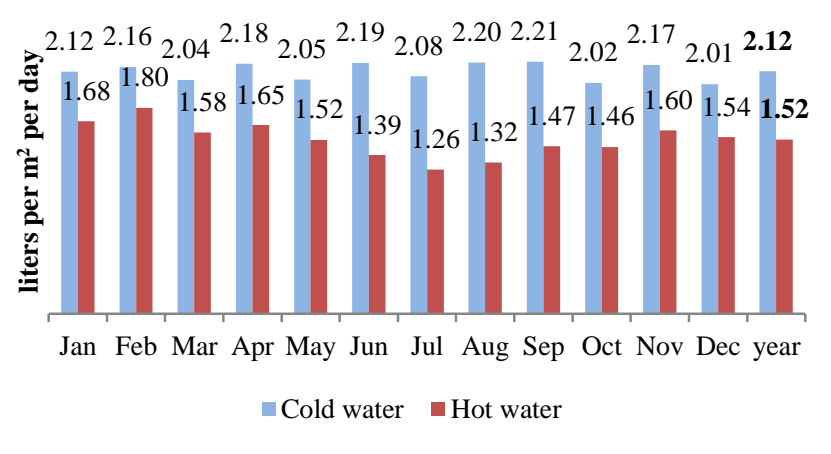

Fig. 3. Daily consumption of domestic cold water (DCW) and domestic hot water (DHW) in apartment buildings (litres per $\mathrm{m}^{2}$ per day).

To achieve the objective of the study, the authors have analysed data on DHW consumption and heat consumption in the DHW system.

Average annual DHW consumption ratio is $42 \%$ of total consumption. Fig. 4 shows DHW consumption ratios and variations per month.

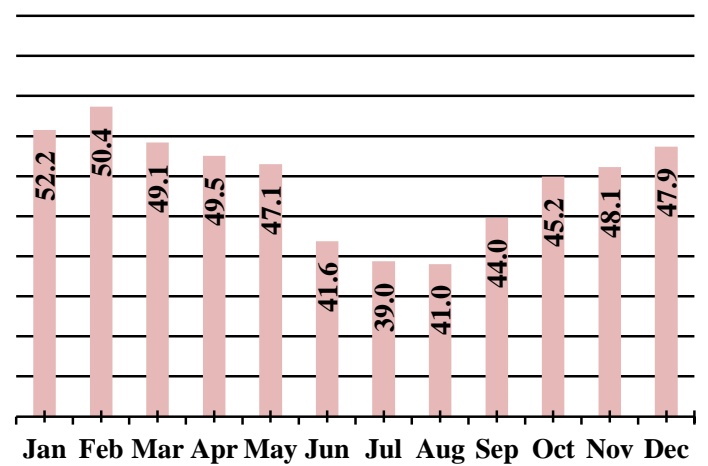

Fig. 4. The ratio $(\%)$ of consumption of domestic hot water to the total consumption in apartment buildings per month

Figure 5 shows the variations ratio of DHW, DCW and total water consumption against the relevant annual average. 


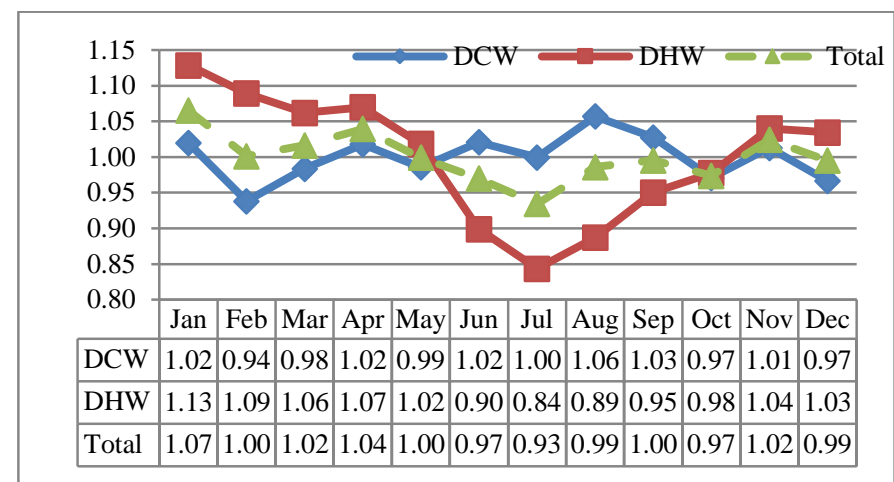

Fig. 5. The variations ratio of DHW, DCW and total water consumption against the relevant annual average.

\section{DHW consumption characteristics}

The study shows specific DHW indicators on the heated area per household and per person (Table 2) and correlation of DHW consumption of these indicators (Figures 6-8). The most accurate data on DHW consumption is per person (Fig. 8).

TABLE 2

DHW CONSUMPTION INDICATORS

\begin{tabular}{|c|c|c|c|c|}
\hline & Minimum & Maximum & Average & $\begin{array}{l}\text { R- } \\
\text { squared } \\
\text { value }\end{array}$ \\
\hline \multicolumn{5}{|c|}{ DHW daily consumption, litres per day } \\
\hline Riga & 1.10 & 2.73 & 1.86 & 0.880 \\
\hline $\begin{array}{l}\text { Reference values* } \\
\text { (Riga) }\end{array}$ & 1.13 & 1.48 & 1.32 & - \\
\hline \multicolumn{5}{|c|}{ - $\quad$ per household } \\
\hline Riga & 55.7 & 142.6 & 92.8 & 0.866 \\
\hline $\begin{array}{l}\text { Reference } \\
\text { values** }\end{array}$ & \multicolumn{4}{|c|}{$\begin{array}{l}100.2 \text { (tapping program No 2) } \\
199.8 \text { (tapping program No } 3 \text { ) }\end{array}$} \\
\hline \multicolumn{5}{|l|}{ - $\quad$ per person } \\
\hline Riga & 24.2 & 60.2 & 41.0 & 0.946 \\
\hline $\begin{array}{l}\text { Reference } \\
\text { value*** }\end{array}$ & \multicolumn{4}{|c|}{36.0 (tapping program No 1) } \\
\hline \multicolumn{5}{|c|}{$\begin{array}{l}* \text { calculated according B.2 of annex B of standard EN 15316-3-1 } \\
* * \text { A. } 2 \text { and A.3 of annex A of standard EN 15316-3-1 } \\
* * * \text { A. } 1 \text { annex A of standard EN 15316-3-1 }\end{array}$} \\
\hline
\end{tabular}

By comparing DHW daily consumption indicators to default values set out in Annex A "Tapping Program for Single Family Dwellings" of standard EN 15316-3-1, the authors have found out that average DHW daily consumption of 41.0 litres per person per day is close to the default value of 36 litres per person per day, determined in Table A.1 'Tapping program No. 1'. Taking into account that the standard default value is set for equivalent hot water litres at $60^{\circ} \mathrm{C}$, average DHW daily consumption in the investigated buildings with the temperature correction from $50^{\circ} \mathrm{C}$ to $60^{\circ} \mathrm{C}$ would be closer to the standard value.

DHW daily consumption maximum value of 76.2 litres per household is less than default values of 100.2 litres per dwelling, determined in Table A.2 ('Tapping program No. 2.') and is very different from the default value of 199.8 litres per dwelling, determined in Table A.3 ('Tapping program No. 3.').

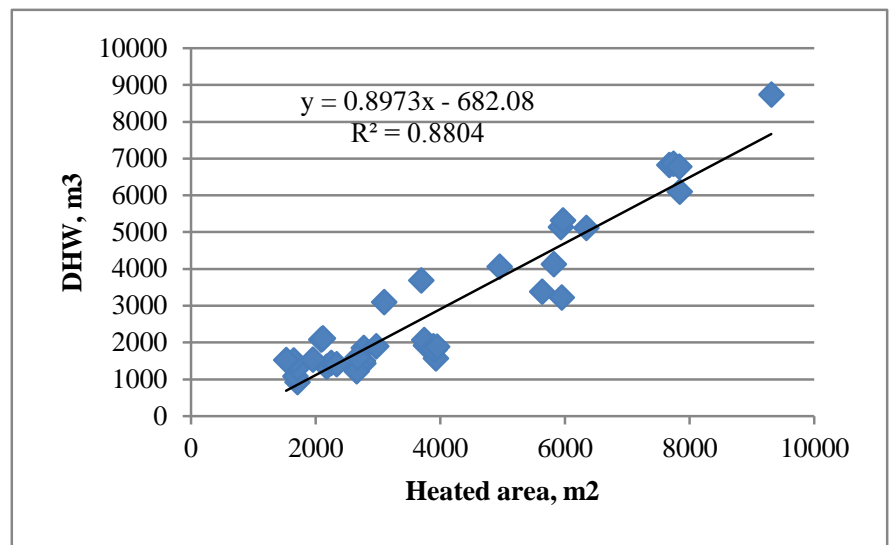

Fig. 6. Correlation of DHW consumption $\left(\mathrm{m}^{3}\right)$ to heated area $\left(\mathrm{m}^{2}\right)$ (39 buildings in Riga)

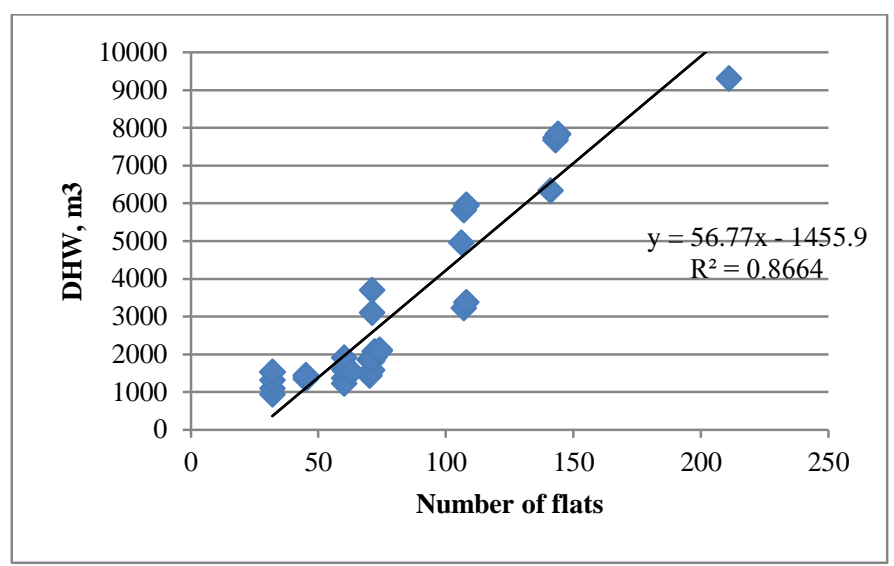

Fig. 7. Correlation of DHW consumption $\left(\mathrm{m}^{3}\right)$ to the number of households (39 buildings in Riga)

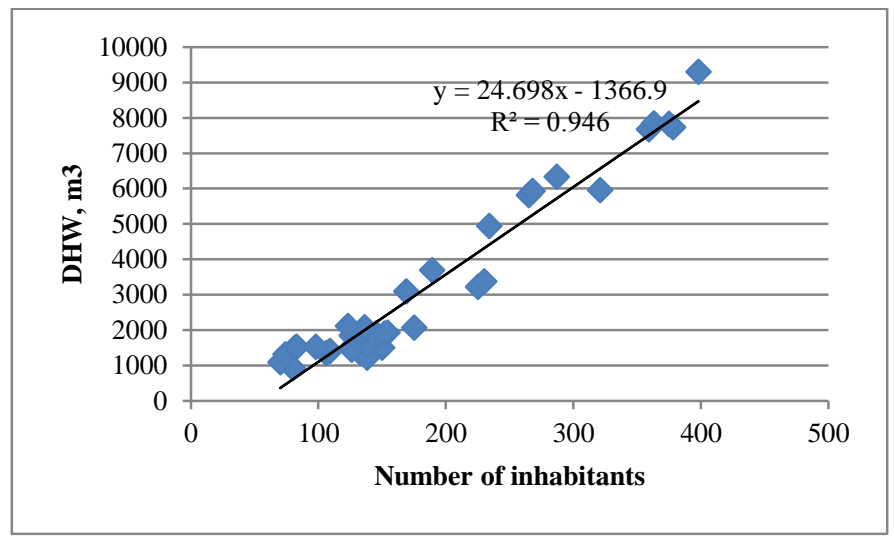

Fig. 8. Correlation of DHW consumption $\left(\mathrm{m}^{3}\right)$ to the number of inhabitants (39 buildings in Riga)

In addition, the study shows that DHW consumption differs by season:

- $94 \%$ of yearly average consumption in the non-heating period (May-September),

- $106 \%$ of yearly average consumption in the heating period (November-March). 
Data on October and April are not taken into account because heating is started or stopped in these months.

Seasonal DHW consumption variations are identified in other researches [12], [25], [26]. Significant factor which affects the consumption of DHW is variation of supplied cold water temperature during the year.

Total heat consumption in the investigated buildings is from 164 to 225 (average 189 ) $\mathrm{kWh}$ per $\mathrm{m}^{2}$ per annum.

To determine the energy consumption for DHW consumption and DHW circulation loop, the authors used data on energy consumption and DHW consumption in the nonheating period (May-September).

The energy consumption $Q_{w}$ for DHW heating for a period is calculated as follows (1):

$$
Q_{w}=V \frac{\rho_{w} C_{w}}{3600} \cdot\left(\theta_{w, d e l}-\theta_{w, o}\right)
$$

where $Q_{w}$ - the energy consumption for DHW heating, kWh; $V$ - the DHW consumption per period, $\mathrm{m}^{3} ; \rho_{w}$ - the water density at temperature $\theta_{w, o}, \mathrm{~kg} / \mathrm{m}^{3} ; C_{w}$ - the water specific heat capacity, $\mathrm{J} / \mathrm{kg} \mathrm{K} ; \theta_{w, d e l}$ - the temperature of cold water $\left({ }^{\circ} \mathrm{C}\right) ; \theta_{w, o}-$ the temperature of DHW $\left({ }^{\circ} \mathrm{C}\right) ; 3600$ - number to take into account for conversion from mega joules to kilowatt hours.

In the investigated buildings, the delivered temperature of cold water ranges from 5 to $15{ }^{\circ} \mathrm{C}$ during the year; temperature of heated water from heat exchanger ranges from 50 to $55^{\circ} \mathrm{C}$ (the temperature drops on circulation loop about five to ten degrees, in the calculation used temperature difference is 40 degrees). Energy consumption necessary to heat $1 \mathrm{~m}^{3}$ of cold water depending on the temperatures difference are shown on table 3. The variations of energy consumption depending the deviation of average temperature shown the error margin of energy needs for DHW consumption.

The energy consumption for DHW needs varies from 18.8 to 46.3 and average is $33.0 \mathrm{kWh}$ per $\mathrm{m}^{2}$ annually in investigated apartment buildings.

TABLE 3

HEAT CONSUMPTION DEPENDING ON DIFFERENCE OF INLET AND HEATED WATER TEMPERATURE

\begin{tabular}{|c|c|c|c|c|}
\hline \multirow{2}{*}{$\begin{array}{c}\text { Temperatu } \\
\text { re of the } \\
\text { inlet cold } \\
\text { water, } \\
{ }^{\circ} \mathrm{C}\end{array}$} & $\begin{array}{c}\text { Temperatures } \\
\text { difference if } \\
\text { average } \\
\text { temperature of } \\
\text { DHW } \\
\text { circulation } \\
\text { loop is }+50{ }^{\circ} \mathrm{C}, \\
\text { degrees }\end{array}$ & $\begin{array}{c}\text { The energy } \\
\text { content for } \\
\text { heating of } \\
1 \mathrm{~m}^{3} \text { of cold } \\
\text { water, } \\
\mathrm{kWh} \text { per } 1 \mathrm{~m}^{3}\end{array}$ & $\begin{array}{c}\text { The variations of energy } \\
\text { consumption depending } \\
\text { deviation from average } \\
\text { temperature }(40 \\
\text { degrees) }\end{array}$ \\
\cline { 5 - 6 } & $\begin{array}{c}\mathrm{kWh} \text { per } \\
1 \mathrm{~m}^{3}\end{array}$ & percentage \\
\hline+6 & 44 & 50,4 & +4.6 & $+10 \%$ \\
\hline+8 & 42 & 48,1 & +2.3 & $+5 \%$ \\
\hline$+\mathbf{1 0}$ & $\mathbf{4 0}$ & $\mathbf{4 5 , 8}$ & 0 & - \\
\hline+12 & 38 & 43,6 & -2.2 & $-5 \%$ \\
\hline+14 & 36 & 41,3 & -4.5 & $-10 \%$ \\
\hline
\end{tabular}

Calculation results of heat energy average values per $\mathrm{m}^{2}$ of heated area per month are shown in Fig. 9.

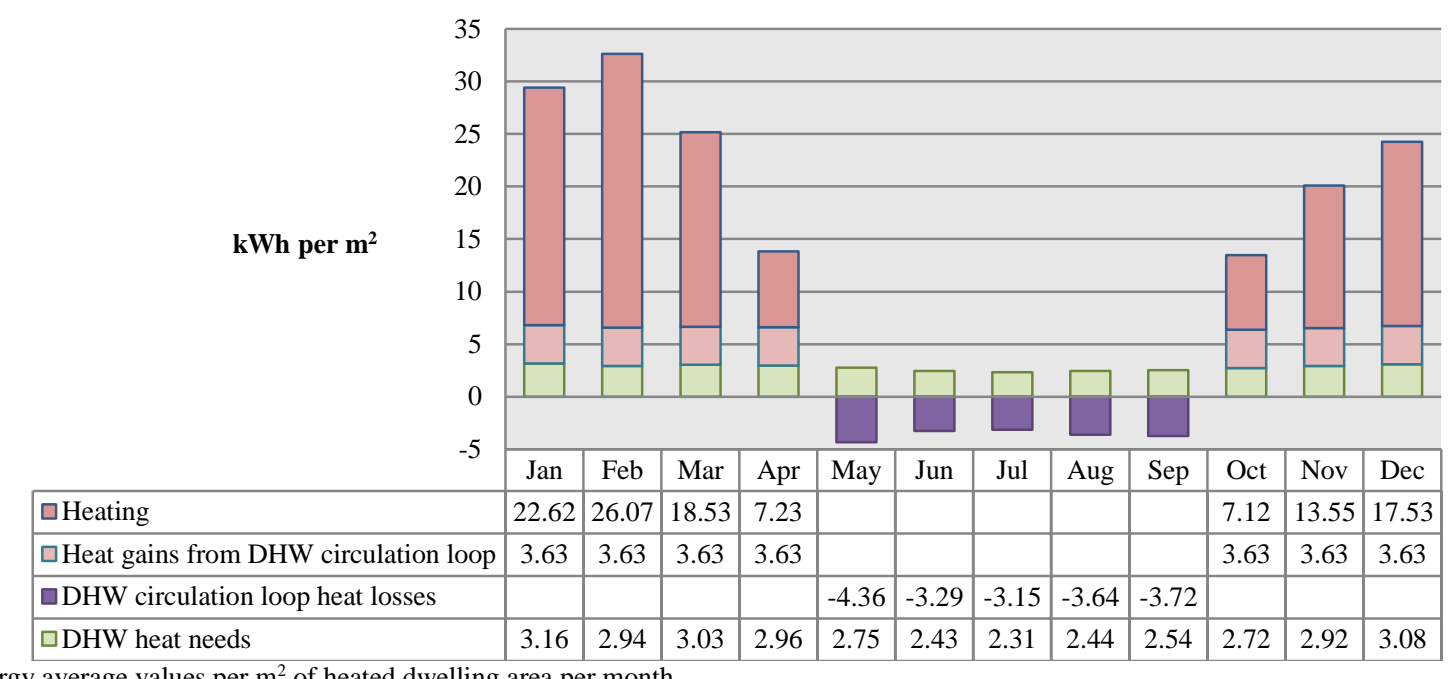

Fig. 9. Heat energy average values per $\mathrm{m}^{2}$ of heated dwelling area per month

During the heating season DHW circulation loop losses is recoverable for heating needs. Thus the losses from DHW system is heat gains for whole building during heating season.

During the non-heated season, the ratio of DHW circulation loop losses in the investigated buildings ranges from 35 to $79 \%$ from total heat consumption, and the average loss ratio is $56 \%$.

The DHW circulation losses in most cases range from 12.9 to $23.0 \mathrm{kWh}$ per $\mathrm{m}^{2}$ in the investigated buildings during the nonheating season. There are two extremely different results (5.3 and $32.1 \mathrm{kWh}$ per $\mathrm{m}^{2}$ ), which are outside normal values. Average DHW circulation losses are $18.0 \mathrm{kWh}$ per $\mathrm{m}^{2}, 0.97$ MWh per households during the non-heating season (Table 4).
TABLE 4

HEAT LOSSES FROM DHW CIRCULATION LOOP INDICATORS

\begin{tabular}{|l|c|c|c|}
\hline \multirow{2}{*}{} & \multicolumn{3}{|c|}{$\begin{array}{r}\text { Heat losses from DHW circulation loop } \\
\text { during the non-heating season }\end{array}$} \\
\cline { 2 - 4 } & Minimum & Maximum & Average \\
\hline kWh per $\mathrm{m}^{2}$ & 12.9 & 23.0 & 18.0 \\
\hline MWh per household & 0.53 & 1.42 & 0.94 \\
\hline
\end{tabular}

The evaluation of DHW circulation losses correlation to the heated area and to the number of households showed that more 
accurate data can be obtained from the heated area (Figures 1011).

In addition, the authors have compared DHW circulation losses by different building characteristics. The study shows that DHW circulation losses does not markedly depend on heat consumption for DHW needs (Figure 12), number of apartments, inhabitants, storeys in building.
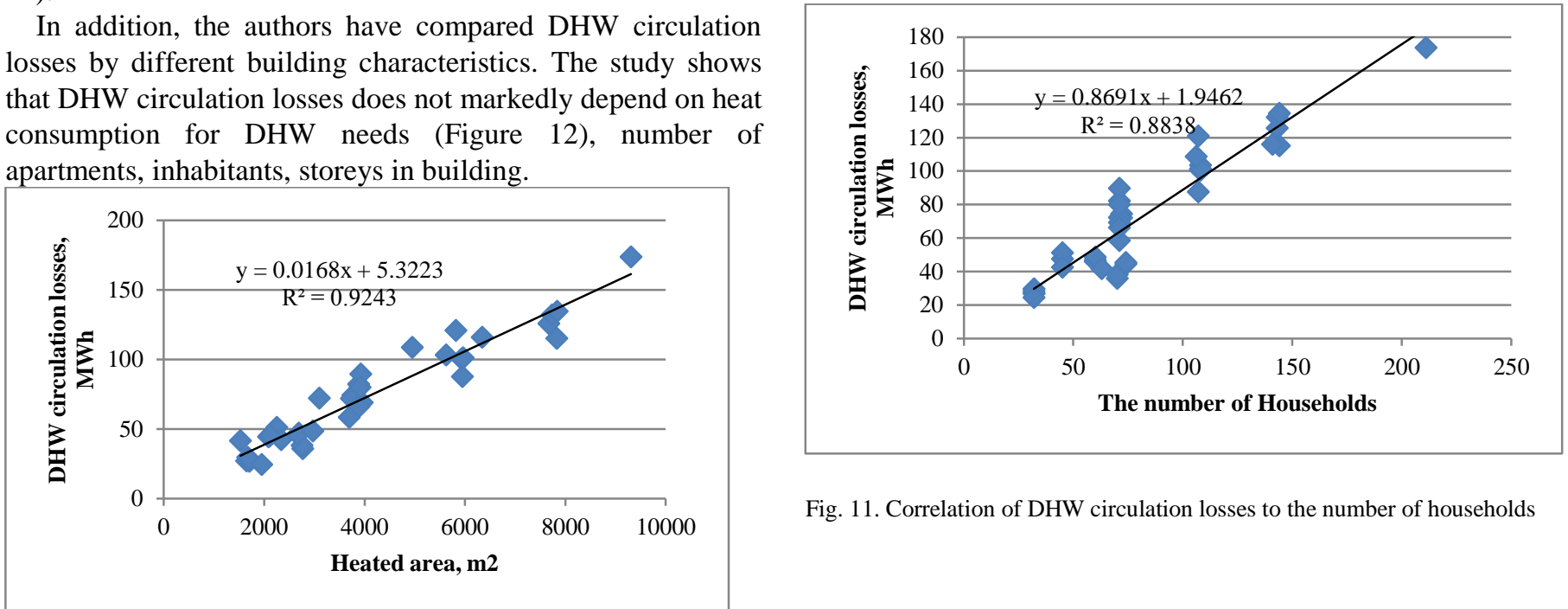

Fig. 11. Correlation of DHW circulation losses to the number of households

Fig. 10. Correlation of DHW circulation losses to the heated area $\left(\mathrm{m}^{2}\right)$

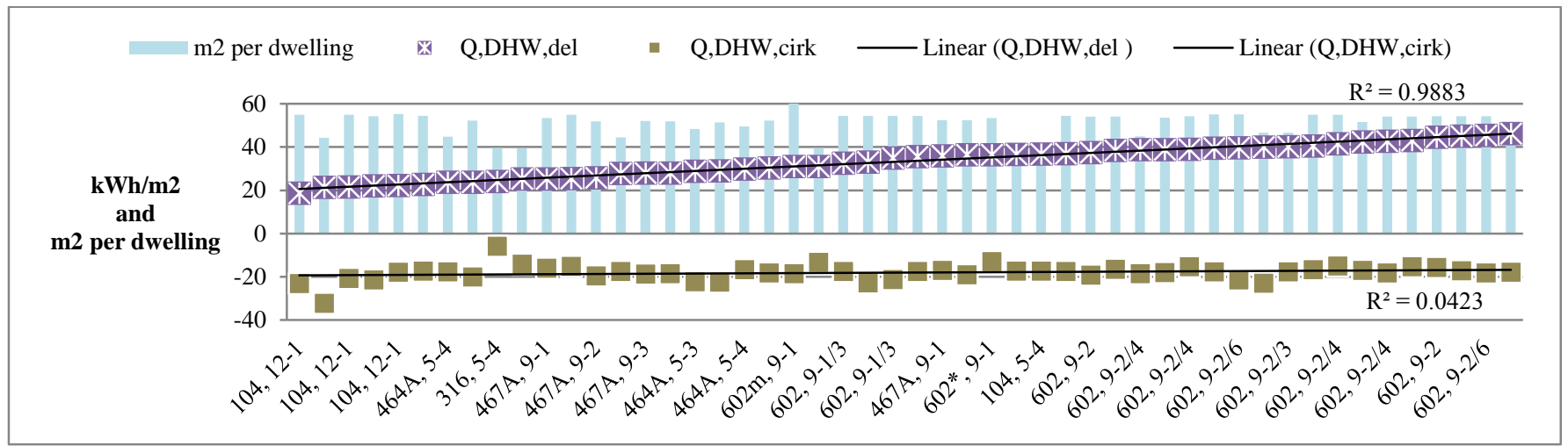

Fig. 12. Heat consumption for DHW needs and DHW circulation losses arranged by the space area of households

\section{Assessment of DHW cirulation losses}

The authors carried out a comparison of different calculation models for assessment of thermal losses of DHW circulation loop:

estimation based on metered heat and DHW consumption data on non-heating season (the method and results described above);

- Calculation of thermal losses from circulation loop based on physical approach according to standard EN 15316-3-2.

- Calculation of thermal losses from circulation loop based on physical approach according to standard EN 15316-3-2 using default values from annex D of the standard.

The general determination of thermal losses of a circulation loop comprising a number of pipe section $i$ is given by:

$Q_{W, \text { dis }, l s, c o l, o n}=\sum_{i} U_{W, i} \cdot L_{W, i} \cdot\left(\theta_{W, \text { dis,avg }, i}-\theta_{a m b, i}\right) \cdot t_{W}$

$Q_{w, d i s, l s, c o l, o n}$ - the linear transmittance of pipe section $i$ during period of circulation, $\mathrm{Wh} /$ period, $U_{w, i}-$ the linear thermal transmittance of pipe section $i(\mathrm{~W} / \mathrm{mK}), L_{w, i}-$ the length of pipe section $i(\mathrm{~m}), \Theta_{w, d i s, a v g, i}-$ the average hot water temperature of pipe section $i\left({ }^{\circ} \mathrm{C}\right), \theta_{a m b, i}-$ the average ambient temperature around pipe section $i\left({ }^{\circ} \mathrm{C}\right)$, $t_{w}$ - calculation period at the corresponding temperature, $\theta_{w, d i s, a v g, i}(\mathrm{~h} /$ period),

(indices: $\mathrm{W}$ - domestic hot water, dis - distribution, ls losses, col - circulation loop (collective), avg - average, $\mathrm{amb}$ - ambient)

The DHW circulation system of investigated buildings has the following features:

- $\quad$ vertical distribution with known number of circulation loops in building section for each building type;

- the circulation loops run continuously all the time;

- $\quad$ each apartment has one towel rail on the circulation loop.

Thus authors have work out unified formulas for calculation of length of circulation loop sections for investigated buildings (Table 5). The domestic hot water distribution system comprises three different pipe sections (figure 13):

- distribution from the heat exchanger to the vertical supply pipes on basement (section $\mathrm{LV}_{\mathrm{V}}$ ),

- main supply pipes on heated area comprise: vertical pipes (section $\mathrm{L}_{\mathrm{S} 1}$ ) and individual towel rails (section $\mathrm{L}_{\mathrm{S} 2}$ ),

- the individual branching pipes to the user outlets on dwellings. Losses from individual branching pipes are not part of circulation loop and losses are part of DHW consumption. 


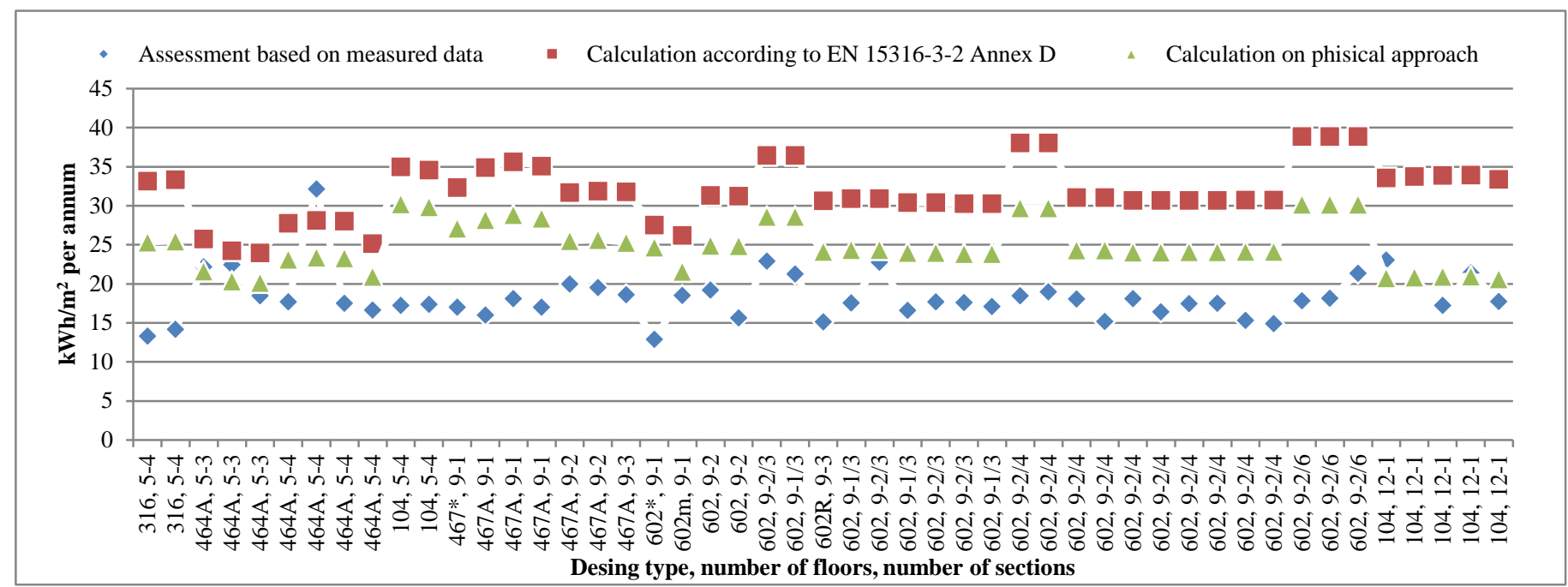

Fig. 14. Calculation results for circulation losses by different assessment methods.

TABLE 7

DHW CIRCULATION LOSSES BY VARIOUS TYPES OF APARTMENT BUILDINGS DURING THE NON-HEATING SEASON

\begin{tabular}{|c|c|c|c|c|c|c|c|c|}
\hline \multirow{3}{*}{$\begin{array}{l}\text { Type of } \\
\text { standard } \\
\text { design } \\
\text { (number of } \\
\text { buildings) }\end{array}$} & \multirow[b]{3}{*}{$\begin{array}{c}\text { Number } \\
\text { of } \\
\text { floors }\end{array}$} & \multirow{2}{*}{\multicolumn{3}{|c|}{$\begin{array}{l}\text { Assessment result } \\
\text { for design type }\end{array}$}} & \multicolumn{4}{|c|}{ Calculation on physical approach } \\
\hline & & & & & & model & Defa & dard model \\
\hline & & $\begin{array}{c}\min \\
\mathrm{kWh} \\
\text { per } \mathrm{m}^{2}\end{array}$ & $\begin{array}{c}\max \\
\mathrm{kWh} \\
\text { per } \mathrm{m}^{2}\end{array}$ & $\begin{array}{c}\text { average } \\
\mathrm{kWh} \\
\text { per } \mathrm{m}^{2}\end{array}$ & $\begin{array}{l}\mathrm{kWh} \\
\text { per } \mathrm{m}^{2}\end{array}$ & $\begin{array}{c}\text { differ from } \\
\text { average } \\
\text { assessed } \\
\text { result, \% }\end{array}$ & $\begin{array}{l}\mathrm{kWh} \\
\text { per } \mathrm{m}^{2}\end{array}$ & $\begin{array}{c}\text { differ from } \\
\text { assessed } \\
\text { result, \% }\end{array}$ \\
\hline $316(2)$ & 5 & 13.3 & 14.2 & 13.7 & 25.4 & +85 & 33.2 & +142 \\
\hline 464A (7) & 5 & 17.5 & 32.1 & 21.0 & 21.8 & +9 & 26.1 & +30 \\
\hline $104(2)$ & 5 & 17.2 & 17.4 & 17.3 & 30.0 & +74 & 34.8 & +101 \\
\hline $602(15)$ & 9 & 12.9 & 22.9 & 18.0 & 25.2 & +38 & 31.7 & +73 \\
\hline $467 \mathrm{~A}(7)$ & 9 & 16.0 & 20.0 & 17.8 & 27.0 & +51 & 33.3 & +86 \\
\hline $104(5)$ & 12 & 17.3 & 23.0 & 20.0 & 22.8 & +15 & 33.7 & +70 \\
\hline Average (38) & & $\underline{13.3}$ & 32.1 & $\underline{18.3}$ & 24.7 & +36 & 31.6 & +74 \\
\hline
\end{tabular}

In addition the authors assessed circulation heat losses ratio by pipe sections. For this assessment author used calculation model on physical approach with the actual input values (table 8) except the average ambient temperature around pipe section in unheated basement on heating season $\left(+10^{\circ} \mathrm{C}\right)$.

TABLE 8

DHW CIRCULATION LOSSES RATIO BY PIPE SECTIONS

\begin{tabular}{|c|c|c|c|c|c|c|c|}
\hline & \multicolumn{6}{|c|}{$\begin{array}{c}\text { Circulation losses ratio } \\
\text { by pipe sections }\end{array}$} \\
\hline $\begin{array}{c}\text { Type of } \\
\text { standard } \\
\text { design }\end{array}$ & $\begin{array}{c}\text { Number of } \\
\text { floors }\end{array}$ & \multicolumn{3}{|c|}{$\begin{array}{c}\text { Non-heating } \\
\text { season }\end{array}$} & \multicolumn{5}{c|}{$\begin{array}{c}\text { Heating } \\
\text { season }\end{array}$} \\
\hline 316 & 5 & 11 & 56 & 33 & 13 & 55 & 32 \\
\hline $464 \mathrm{~A}$ & 5 & 12 & 57 & 32 & 14 & 55 & 31 \\
\hline 104 & 5 & 10 & 60 & 31 & 12 & 58 & 30 \\
\hline 602 & 9 & 12 & 67 & 22 & 14 & 65 & 21 \\
\hline $467 \mathrm{~A}$ & 9 & 12 & 64 & 24 & 15 & 62 & 23 \\
\hline 104 & 12 & 10 & 64 & 26 & 12 & 62 & 26 \\
\hline
\end{tabular}

The study shows that the rate of circulation heat losses on unheated basement varies 10 to $12 \%$ during non-heating season and 12 to $15 \%$ during heating season.

The rate of circulation heat losses of vertical distribution circulation loop pipes and individual towel rails varies depending on the number of floors in the building. Depending of season the rate of circulation heat losses of vertical distribution circulation loop pipes varies 55 to $60 \%$ for 5 floor buildings and 62 to $67 \%$ for 9 or 12 floor buildings. Whereas the rate of circulation heat losses of individual towel rails varies 30 to $33 \%$ for 5 floor buildings and 21 to $26 \%$ for 9 or 12 floor buildings.

\section{CONCLUSION}

The study clearly demonstrates that making assessment of energy performance of collective DHW system of apartment buildings, the energy needs for DHW system should be divided into energy for DHW consumption needs for inhabitants and energy for distribution losses.

the study shows that the energy consumption for the energy for DHW consumption needs depend on the number of inhabitants while energy losses for distribution including collective circulation loop depends on distribution pipes length and pipes thermal characteristics.

The energy consumption for DHW needs varies from 18.8 to 46.3 and average is $33.0 \mathrm{kWh}$ per $\mathrm{m}^{2}$ annually in investigated apartment buildings.

The study shows that DHW consumption in the apartment buildings most accurate correlated based on the number of inhabitants and less accurate correlated by the number of flats and by the heated area. 
The DHW consumption varies by season in apartment buildings. DHW consumption was $94 \%$ of yearly average in the non-heating period (May-September) and 106\% of yearly average in the heating periods (November-March). In order to obtain more precise results it may be taken into account when evaluating energy consumption of DHW system in residential buildings.

The energy losses for DHW distribution including collective circulation loop ranges from 12.9 to 23.0 and average is 18.0 $\mathrm{kWh}$ per $\mathrm{m}^{2}$ in investigated apartment buildings during nonheating season. These indicators can be applied to full year as the energy losses for circulation loop is recoverable during heating season exclude losses from distribution pipes on unheated basement.

The DHW system circulation losses depend on distribution pipes length and pipes thermal characteristics. In addition, in this study it is shown that heat losses from DHW circulation loop differ by different design types. The study shown that DHW circulation losses does not markedly depend on heat consumption for DHW needs, number of apartments, inhabitants or storeys in apartment building but correlation of DHW circulation losses to heated area is significant.

The study has also detected that some consumption characteristics of DHW for apartment buildings are different from the values given in the standard EN 15316-3-1 (Heating systems in buildings - Method for calculation of system energy requirements and system efficiencies - Part 3-1: Domestic hot water systems, characterisation of needs (tapping requirements)); therefore, the standard should be specified in national annexes. The appropriate national annexes of EPBD standards for DHW systems are not developed in Latvia.

The authors believes that calculation of DHW circulation losses should be based on physical approach according to standard EN 15316-3-2 and with nationally adapted default values. The calculations result based on physical approach should be validated with assessment based on measured data of heat and DHW volume consumption since the linear thermal transmittance of pipe section, the average hot water temperature of pipe section, the average ambient temperature around pipe section have significant impact to the calculation results.

The assessed DHW circulation heat losses ratio by pipe sections has shown the potential to save losses on DHW circulation pipe sections.

The DHW circulation losses from main vertical pipes on heated area rate 55 to $67 \%$ of the total. These sections of pipes are not insulated but it is recommended to do it in future.

\section{ACKNOWLEDGEMENTS}

The authors express many thanks to JSC "Rīgas siltums", Ltd. "Rīgas namu pārvaldnieks" for support in this research.

\section{REFERENCES}

[1] B. Bøhm, Production and distribution of domestic hot water in selected Danish apartment buildings and institutions. Analysis of consumption, energy efficiency and the significance for energy design requirements of buildings, Energy Conversion and Management 67 (2013) 152-159. http://dx.doi.org/10.1016/j.enconman.2012.11.002

[2] K. Yliniemi, J. Delsing, J. van Deventer, Experimental verification of a method for estimating energy for domestic hot water production in a 2stage district heating substation, Energy and Buildings 41 (2009) 169174. http://dx.doi.org/10.1016/j.enbuild.2008.08.008

[3] L. Gullev, M. Poulsen, The Installation of Meters Lead to Permanent Changes in Consumer Behaviour, News from DBDH, No. 3, 2006.

[4] T.A. Koiv, A. Toode, Trends in domestic hot water consumption in Estonian apartment buildings, in: Proceedings Estonian Acad. Sci. Eng., 2006.

[5] C. Kan, H. Yoshino, et al., 2007. Field survey on heating/cooling loads and end-use energy consumption in China. Summary of SHASE Annual Meeting, 387-390.

[6] S. Hokoi, D. Ogura, X. Fu, Y. Rao, Field survey on energy consumption due to hot water supply and cooking in Nanjing and Hefei, China, Frontiers of Architectural Research (2013) 2, 134-146. http://dx.doi.org/10.1016/j.foar.2013.03.001

[7] T. Inoue, S. Mizutani, T. Tanaka, 2006. Energy consumption in housing on the basis of national scale questionnaire: analysis of influence of various factors on annual energy consumption Part2. Journal of Environmental Engineering, Architectural Institute of Japan 606,75-80 Aug.2006.

[8] Y. Hasegawa, T. Inoue, 2004. Energy consumption in housing on the basis of national scale questionnaire: study on influence of residential characteristic and dispersion of energy consumption Part 1. Journal of Environmental Engineering, Architectural Institute of Japan 583,23-28 Sep.2004.

[9] S. Murakami, K. Bogaki, T. Tanaka, H. Hayama, Y. Yoshino, S. Akabayashi, T. Inoue, A. Iio, S. Hokoi, A. Ozaki, Y. Ishiyama, Y.,2006. Detail survey of long-term energy consumption for 80 houses in principle cities of Japan - Description of the houses and end use structure of annual energy consumption. Architectural Institute of Japan 603, 93 100 .

[10] R. Hendron and J. Burch, Development of Standardized Domestic Hot Water Event Schedules for Residential Buildings, Presented at Energy Sustainability 2007, Long Beach, California Jun 27-30, 2007 http://dx.doi.org/10.1115/es2007-36104

[11] A. Lowenstein, and C. Hiller, 1996, "Disaggregating Residential Hot Water Use," ASHRAE Transaction Symposia, January 1996, Atlanta, GA: ASHRAE.

[12] C. Aguilar, D.J. White, and David L. Ryan, Domestic Water Heating and Water Heater Energy Consumption in Canada, April 2005, CBEEDAC 2005-RP-02.

[13] B. Bøhm, PO. Danig. Monitoring the energy consumption in a district heated apartment building in Copenhagen, with specific interest in the thermodynamic performance. Energy Build 2004;36:229-36. http://dx.doi.org/10.1016/j.enbuild.2003.11.006

[14] F. Schrøder, Cirkulationstab i varmt brugsvandsanlæg er langt større end antaget (Circulation heat losses much bigger than previously estimated). Danish HVAC J 2004;4:36-40.

[15] European Parliament and Council of the European Union 2010. Directive 2010/31/EU of the European Parliament and the Council of 19 May 2010 on the energy performance of buildings (recast). Official Journal of the European Union L 153/13-35 of 18.6.2010.

[16] European Parliament and Council of the European Union 2002. Directive 2002/91/EC of the European Parliament and the Council of 16 December 2002 on the energy performance of buildings. Official Journal of the European Communities L 1/64-71 of 4.1.2003.

[17] EN 15316-1 - Heating systems in buildings - Method for calculation of system energy requirements and system efficiencies - Part 1: General.

[18] J. Zirngibl, Information paper on EN 15316-1 Heating systems in buildings - Method for calculation of system energy requirements and system efficiencies - Part 1: General, IEE-CENSE, European Communities, 2009.

[19] Compilation of Information Papers introducing the CEN standards concerning Heating Systems and Domestic Hot Water - Booklet 3: Heating and DHW Systems, IEE-CENSE, European Communities, 2010.

[20] H. van Wolferen, Information paper on EN 15316-3-1 Domestic Hot Water systems - Characterisation of Needs (tapping requirements), IEECENSE, European Communities, 2008.

[21] EN 15316-3-1 - Heating systems in buildings - Method for calculation of system energy requirements and system efficiencies - Part 3-1: Domestic hot water systems, characterisation of needs (tapping requirements). 
[22] EN 15316-3-2 - Heating systems in buildings - Method for calculation of system energy requirements and system efficiencies - Part 3-2: Domestic hot water systems, distribution.

23] H. van Wolferen, Information paper on EN 15316-3-2 Domestic Hot Water systems - Distribution, IEE-CENSE, European Communities, 2008.

[24] Statistics Database, ENG08. ENERGY BALANCE, thsd toe (NACE Rev.2). Central Statistical Bureau of Latvia, data.csb.gov.lv.

[25] R. Burzynski, M. Crane, R. Yao, A review of domestic hot water demand calculation methodologies and their suitability for estimation of the demand for Zero Carbon houses, TSBE EngD Conference, TSBE Centre, University of Reading, Whiteknights Campus, RG6 6AF, 6th July 2010, http://www.reading.ac.uk/tsbe/.

[26] F.S. Goldner, "Energy Use and Domestic Hot Water Consumption", New York State Energy Research and Development Authority, Report 94-19, 1994. 